|| ISSN(online): 2589-8698 || ISSN(print): 2589-868X ||

International Journal of Medical and Biomedical Studies

Available Online at www.ijmbs.info

NLM (National Library of Medicine ID: 101738825)

Index Copernicus Value 2019: 79.34

Original Research Article

Volume 5, Issue 8; August: 2021; Page No. 218-219

\title{
CLINICAL PROFILE OF TYPHOID FEVER IN CHILDREN
}

\section{Dr. Shaitan Singh Balai}

MD Pediatrics

Article Info: Received 19 June 2021; Accepted 16 August 2021

DOI: https://doi.org/10.32553/ijmbs.v5i8.2117

Corresponding author: Dr. Shaitan Singh Balai

Conflict of interest: No conflict of interest.

\section{Abstract}

Background: The present study describes the clinical presentation of enteric fever at a tertiary care centre.

Methods: The study was a hospital based prospective observational study conducted on children of age 2 -18 years who presented with fever of 5 days or more with clinical signs and symptoms suggestive of typhoid fever and positive Widal test or Typhidot tests were included in the study. The demographic and clinical features of the patients were described.

Results: All the children presented with fever as the main complaint (100\%). Commonest sign noticed was toxic look (84\%) followed by coated tongue (79\%) and splenomegaly (61\%). Hepatomegaly was also noted in $34 \%$ of cases.

Conclusion: This study was undertaken to observe the clinical profile of typhoid fever in children admitted in a tertiary care hospital. Typhoid fever remains to be as an endemic disease in this locality. All the signs and symptoms of the disease are nonspecific common with other acute febrile illnesses; a definitive diagnosis of the disease is required for treatment and to prevent transmission.

Keywords: Enteric fever, Splenomegaly, Toxic look

\section{Introduction}

Typhoid fever is a life-threatening disease occurring more frequently in under developed areas of the world and it continues to pose a major public health problem. There are around 16 million new enteric fever cases reported globally. ${ }^{1}$ The annual incidence of enteric fever has been reported as more than 13 million cases in Asia alone and it causes annual deaths of more than 0.6 million across the world. $^{2}$ The incidence of Typhoid fever in India is 2.14 per thousand populations. ${ }^{3}$ The incidence of typhoid fever in the younger age group is also on the increase and the disease which was reported to be very rare below the age of three years is not correct and now there is documented evidence that enteric fever will not spare any age. ${ }^{4}$ In endemic areas such as India, traditional signs and symptoms in enteric fever are not often observed. Unusual presentations lead to diagnostic dilemma and may delay the diagnosis of typhoid fever ${ }^{5-7}$. The present study describes the clinical presentation ofenteric fever at a tertiary care centre in Rajasthan.

\section{Methods}

The study was a hospital based prospective observational study. The parents of the children were informed about the research and its objectives, and written informed consent was obtained from them.

Children of age 2-18 years who presented with fever of 5 days or more with clinical signs and symptoms suggestive of typhoid fever and positive Widal test or Typhidot tests were included in the study.

The demographic and clinical features of the patients were described. All children were enquired about a careful history including family history of similar illness and socioeconomic status, source of drinking water.

Children who have been diagnosed as paratyphoid fever by serology like Widal test were clearly excluded from the study. Total leukocyte count was done in all patients.

\section{Results}

Table 1: Symptoms at the time of admission to hospital

\begin{tabular}{|l|l|l|}
\hline Symptoms & Number of patients & Percentage \\
\hline Fever & 100 & 100.00 \\
\hline Anorexia & 61 & 61.00 \\
\hline Vomiting & 35 & 35.00 \\
\hline Diarrohea & 16 & 16.00 \\
\hline Abdominal pain & 33 & 33.00 \\
\hline Constipation & 19 & 19.00 \\
\hline Headache & 56 & 56.00 \\
\hline Cough & 19 & 19.00 \\
\hline
\end{tabular}


All the children presented with fever as the main complaint (100\%). Loss of appetite and headache were the next common complaints reported by $61.00 \%$ cases.

Table 2: Signs at the time of admission to the hospital

\begin{tabular}{|l|l|l|}
\hline Sign & Number of patients & Percentage \\
\hline Coated tongue & 79 & 79.00 \\
\hline Anemia & 37 & 37.00 \\
\hline Abdominal tenderness & 28 & 28.00 \\
\hline Toxic look & 84 & 84.00 \\
\hline Hepatomegaly & 34 & 34.00 \\
\hline Splenomegaly & 61 & 61.00 \\
\hline Respiratory infections & 3 & 3.00 \\
\hline
\end{tabular}

Commonest sign noticed was toxic look (84\%) followed by coated tongue (79\%) and splenomegaly (61\%). Hepatomegaly was also noted in $34 \%$ of cases.

\section{Discussion}

All present study subjects presented with fever as the main complaint $(100 \%)$. Loss of appetite and headache were the next common complaints reported by $61.00 \%$ cases.

Study by Modi R reported that gastrointestinal complaints were second most common after fever with abdominal pain noticed in $57.14 \%$ patients and vomiting in $50 \%$ of the patients. $^{7}$

Similar observations were reported by Comeau et al and Kapoor JP et al and Sinha et al. ${ }^{6,9,10}$ However, Joshi et al reported that headache was the most common symptom after fever seen in $52.5 \%$ cases and abdominal pain and vomiting were the other common associated symptoms seen in $22.5 \%$ and $20 \%$ cases respectively. ${ }^{11}$

Commonest sign noticed was toxic look $(84 \%)$ followed by coated tongue (79\%) and splenomegaly (61\%). Hepatomegaly was also noted in $34 \%$ of cases.

Devaranavadagi RA and Srinivasa $\mathrm{S}$ also reported Toxic look $(68 \%)$ as the most common sign followed by coated tongue (49\%), Hepatomegaly (44\%), and other signs. ${ }^{8}$ However, Laishram et al reported coated tongue $(80 \%)$ as the most common sign followed by Hepatomegaly (76\%) and splenomegaly $(38 \%){ }^{12}$

\section{Conclusion}

This study was undertaken to observe the clinical profile of typhoid fever in children admitted in a tertiary care hospital. Typhoid fever remains to be as an endemic disease in this locality. All the signs and symptoms of the disease are nonspecific common with other acute febrile illnesses; a definitive diagnosis of the disease is required for treatment and to prevent transmission.

\section{References}

1. Ivanoff B. Typhoid fever, global situation and WHO recommendations. Southeast Asian J Trop Med Public Health.1995;26supp 2:1-6.

2. Ivanoff B, Levine MM, Lambert PH. Vaccination against typhoid fever: present status. Bull World Health Organ. 1994;72(6):957-71.

3. Kothari A, Pruthi A, Chugh TD. The burden of enteric fever. J Infect Dev Ctries. 2008;2(4):253-9.

4. Garg RA, Krashak R. Typhoid fever before two years of age. Indian Pediatr. 1993;30(6):805-8.

5. Sen S, Goyal RS, Dev R. Ciprofloxacin in the management of multiple drug resistant typhoid fever. Indian Pediatr. 1991;28(4):417-9.

6. Comeau JL, Tran TH, Moore DL, Phi CM, Quach C. Salmonella enterica serotype typhi infections in a Canadian pediatric hospital: a retrospective case series. CMAJ Open. 2013;1(1):E56-61.

7. Modi R. Clinical profile and treatment outcome of typhoid fever in children at a teaching hospital, Ahmedabad, Gujarat, India. Int J Med Sci Public Health. 2016;5:212-6.

8. Devaranavadagi RA, Srinivasa S. A study on clinical profile of typhoid fever in children. Int J Contemp Pediatr. 2017;4:1067-73.

9. Sinha A, Sazawal S, Kumar R, Sood S, Singh B, Reddaiah VP et al. Typhoid fever in children aged less than 5 years. Lancet. 1999;354:734-7.

10. Kapoor JP, Mohan M, Talwar V, Daral TS, Bhargava SK. Typhoid fever in young children. Indian Pediatr. 1985;22:811-3.

11. Joshi BG, Keyal K, Pandey R, Shrestha BM. Clinical profile and sensitivity pattern of Salmonellaserotypes in children: a hospital based study. J Nepal Pediatr Soc. 2011;31(3):180-3.

12. Laishram N, Singh PA. Clinical profile of enteric fever in children. J Evol Med Dent Sci. 2016;5(2):114-6. 